Krakowskie
Studia
Międzynarodowe

Harvey C. Mansfield, Delba Winthrop

\title{
WHAT TOCQUEVILLE SAYS TO LIBERALS AND CONSERVATIVES TODAY
}

Russell Baker once said that in our time people cite Tocqueville without reading him even more than they do the Bible and Shakespeare. Every American president since Eisenhower has quoted him, no doubt without reading him, and some of our professors, to say nothing of other citizens, have picked up their habit of fishing for what they like, and throwing back the rest, in Tocqueville's great work Democracy in America.

It is no mystery why everyone wants Tocqueville's support: his work is both the best book on democracy and the best book on America - two subjects that for Americans, at least, are inseparable. We cannot fail to be interested in a book so renowned but because of a certain laziness whose source is our partisanship, we fail to read it through or read it carefully, lest we come upon something difficult to accept. The purpose here is not to invoke Tocqueville in a vain attempt to transcend partisanship, a possibility he rejected. But perhaps he can do something to raise the awareness of both liberals and conservatives, and get them to see that their own party, and not just the other party, has questions it needs to face.

We address liberals and conservatives rather than independents. Most thinking people are either liberals or conservatives, and most independents, instead of standing above party as they believe, actually pick from both parties unthinkingly, trying to have their cake and eat it too. Tocqueville first lesson to our independents is the inevitability of partisan opinion. For "in all free societies" he says, there exists a set of two opinions "as old as the world". One wants to restrict "popular" or "public" power, the other to extend it indefinitely.

Clearly, the parties of Tocqueville's France were not the same as America's today. Then one party, nostalgic for the traditional order of hierarchy and religion, bitterly rejected the post-revolutionary order in toto, and the other party, zealously championing the Revolution's principles of liberty, equality and frater- 
nity, set itself in opposition to everything - bad or good - associated with the Old Regime. Despite the differences one may find, Tocqueville in fact has a good deal to say about the central doctrines of our conservatives and liberals - self-interest for conservatives and community for liberals. Let us see what he would say to current promoters of these hot ideas.

We begin with conservatives, the party that would narrow popular or public power principally in the name of self-interest. This party, because of its own sometimes inept rhetoric as well as the caricature given it by its opposition, appears as the party of the rich and powerful. It is the party that has long defended "rugged individualism", and is accused of protecting callous self-interest. Tocqueville is, of course, famous for his firm, if no heartfelt, embrace of the American doctrine of self-interest well understood. So he would seem to have much to say to any party that adopts the doctrine. Tocqueville's defenders of self-interest argue from its strength, and rather than urge men to deplore and transcend an inclination so powerful, they defend its legitimacy. They hope to turn self-interest against itself by maintaining that one's own interest is, as a rule, best secured in pursuing a general good. Well understood, self-interest even requires a certain degree of sacrifice. In the end, the doctrine may "form ... citizens who are regulated, temperate, moderate, farsighted, masters of themselves". It is meant to provide a substitute for virtue, instilling the habits of virtue if not requiring elevated motives of generosity or pious self-forgetting. It does not reject religion, but finds it useful for a human purpose. Rather than defining self-interest as obedience to God, the doctrine goes so far as to interpret hopes for the afterlife as an aspect of self-interest.

Self-interest well understood, Tocqueville says, is the moral doctrine best suited to the needs of modern democratic life. His endorsement of it is, however, qualified in several ways that are useful to recall. He never justifies the pursuit of self-interest for its own sake, but only as the best means available to our moralists of encouraging "association". Further, he believes that the doctrine will work only when supported by free political institutions. Third, he stresses that the principle is democratic, as do today's conservatives, because it is within the reach of all. But by the same token, he recognizes that it will not inspire great virtue or even true virtue. In fact, he suggests that it may do little to sustain one aspect of virtue that ought to be within reach of almost all democratic citizens, namely courage. Finally, the doctrine is not quite true. Tocqueville does not try to deny, like some freemarket economists, that everyone has an interest in the common good. On the contrary, he affirms that some concern for the good of others is a part of human nature, a spontaneous impulse rather than behavior learned by adhering to a doctrine.

American conservatives today hardly dare profess any determination to restrict popular power: democratic feeling is too strong for that. But they seek to narrow or contain public power, especially that of the national government. In the form that they espouse the doctrine of self-interest well understood, they want to bolster local and state governments, but even more, they promote private economic enterprise together with the exercise of religion. Here, we know, are the two chief components of the Republican party, economic libertarians and religious or social 
conservatives. Their cooperation, Tocqueville saw, is more than just an uneasy alliance requiring luck or extraordinary political skill. The alliance has a common ground in the shared desire to restrict public power, even if each component wants to protect a quite distinct sphere from government interference.

As their critics point out, conservatives fail to see clearly that an interested self is not necessarily a strong self. Today Americans pride themselves on their "individualism", which they understand in a strong sense. But Tocqueville uses the term pejoratively to refer to the weakness of individuals in a democratic society. Democratic individuals, suppose themselves to be independent, but in fact they are incapable of providing for their own well-being, still less for society as a whole. $\mathrm{He}$ finds something positive in the desire for independence, in the determination to "get government off our backs". It is not, however, the mere hostility to government that conservatives often convey. Instead, he sees an inchoate aspiration for free political institutions in which citizens can be active participants.

Thus there is an important place in a democracy for a party of community to articulate longstanding goals of liberals: security for all, compassion for those in nee, full and equal participation of all citizens in social and political life.

On behalf of liberals Tocqueville willingly affirms - no small concession to them - the justice of democratic equality. So why should popular power, the power of all the people equally, not extend indefinitely? Neither does he deny how could anyone? - that security is a legitimate concern. And even as he holds that self-interest well understood is the most suitable moral doctrine for modern times, he acknowledges that the mores, that is "habits of the heart", will increasingly be shaped by a disposition to compassion. These two inclinations, selfinterest and compassion, are by no means incompatible. Democracy's increasingly equal and similar citizens can all but "feel the pain" of their fellows, and they will readily come to their assistance in case of need because they can identify with them, imagining themselves in trouble and needing help. Democratic citizens tend to experience their common humanity as a common neediness. Thus the compassionate concern they express for the security and dignity of the disadvantaged and elderly, or of elderly parents left financially dependent on their own children, is also a matter of present or potential interest to everyone.

With liberals, Tocqueville shares a critique of "the market", whose unfailing beneficence and sufficiency is often assumed by conservatives. He foresees as clearly as did Marx the cruel indifference to others of modern meritocratic elites. Yet he fully appreciates that the desire for material goods sustaining the modern market is not only universal, but especially characteristic of the middle class. And unlike liberal wishful-thinkers, he doubts that the demand for material goods can be effectively met without generating considerable inequalities. Restiveness drove earlier generations of Americans to the western frontier with an avaricious energy that Tocqueville calls a "sort of heroism". Today Americans are still restive with longing for both material pleasures and equality that are presently beyond their grasp and that set them ever on the move. At the same time, they are insecure in what they already have and their restive motion unravels whatever social ties they 
will have hastily established in passing. It is democracy, not merely the market, that makes community, or even association, difficult. The more we extend democracy, the more we instill the restive, individualizing desire for material goods.

Today, liberals have champions who promise to fight for the people against the rich and powerful. What Tocqueville might say to them is that the people are better served by being enabled to fight for themselves, under a government that directs its energies to shoring up the social and political institutions and habits that make it necessary and possible for citizens to "associate" - or, in today's parlance, to participate.

Tocqueville reserves his most somber rhetoric for a description of a democracy in which citizens are shepherded into his famous "mild despotism", under which power is exercised by "school-master" administrators. Such a government may be well meaning, competent, and effective. But its great appeal is that it promises, with all compassion, to make citizens secure and to promote their happiness, while depriving them, he says sarcastically, of "the pain of living" and "the trouble of thinking".

Modern liberals resemble to some extent the eighteenth-century intellectuals whom Tocqueville analyzed in his later book, The Old Regime. These intellectuals were determined to rationalize human life with the aid of new scientific knowledge. To this end they were eager to do away with traditional authority and institutions, replacing them with a simplified, centralized administration cleansed of partisan politics. Consumed with ambition themselves, they failed to recognize or prize it in others. Their rationalism did not take account of the irrational in human passions, and thus in its political effects turned out to be a new kind of irrationalism that stifles rather than oppresses. Our liberals today have a similar overconfidence in a similar social science, with its focus on security, its preference for centralization, its tendency to simplify problems as well as solutions.

Democratic America, Tocqueville contends, has other, better schools, open to all, and free of charge - its political institutions, both formal and informal. Local governments, epitomized by the New England township, are "primary schools" of freedom, where one acquires the taste for freedom, where one acquires the taste for freedom and learns habits of freedom. Juries, too, are schools, where the people learn how to reign as they reign. In serving, each juror acquires a respect for law, for justice, and for everyone's rights. And in being made to render a verdict, randomly selected citizens, a dozen at a time, learn to take personal responsibility for their actions.

While participating in a vast array of associations - economic, social, moral, intellectual, but especially political - citizens become accomplished in the art and science of association. When individuals pool their efforts, they may be able to meet more of their common needs without the assistance of a strong central government. They become better prepared to preserve their freedom against government, should that ever be necessary. It is always necessary to enlarge citizens' hearts and minds through participation in associations. Here they expose themselves to the various sentiments and ideas democracy can foster in interested, if not 
independent selves, instead of supposing that all are like, as they must do when they show their compassion. Finally, each participant learns to subordinate his or her will to common purposes, as members of a free community should. Especially in political associations, which aspire to the formidable goal of governing society, they can see just how worthwhile it might be to make the effort needed to succeed at associating. As Tocqueville presents associations, they are the people's best hope for becoming the rich and powerful themselves.

Conservatives are right to accept the inevitability of self-interest and the need to understanding it well, and wrong to trust too much in either the market or religion as individual solutions to public problems. Liberals are right when they worry about the well-being of the community as a whole, and wrong when they trust more in compassionate government than in the on-the-job training of democratic politics. Neither conservatives nor liberals say enough about what they as partisans experience: the extent to which their partisanship confirms and corrects the point of view of each party and shows the necessity of the other.

Liberals do not have much to say about the political ambition that drives some of them to seek public office in liberal communities; and conservatives too have trouble understanding ambition from the standpoints of homo economicus or homo religiosus. Tocqueville grants that democracy tends to impoverish ambition by putting it in the service of crass materialism or vulgar self-indulgence. Yet he also finds in democratic politics the potential to keep ambition vigorous and healthy, to diffuse it widely, and to make the self-interest of the rich or powerful beneficial to everyone. Out of self-interest, rich or eminent men who would curry popular favor to gain political office will dissemble their selfishness and pride. Eventually, what begins as a calculated, feigned desire to fight for the people's interest in general prosperity may be transformed by the pleasurable experience of winning an election and reelection, becoming a matter of habit and choice, even of self-imposed obligation. So defenders of self-interest might look to politics to enlighten that interest. And those who oppose self-interest in the name of community might come to see that communities actually need more vigorous self-interest in the form of ambition. The more we nourish widespread ambition, the less we have to fear the overweening power of mild despotism. In that way we can have more government and less dependency.

Both conservatives and liberals have something to learn from Tocqueville on religion. He addresses the political woes of skeptical democratic peoples, who are too much given to unstable desires and brief exertions. Tocqueville recommends that democratic governments extend the horizons of democratic communities by setting distant goals to be achieved by moderate, yet steadfast, ambition. The seemingly limited goal he specifies is seeing to it that political office comes as a reward for skill and effort. But this modest goal is in truth an infinite one. Winning the favor of a democratic electorate with unstable desires will always depend to a certain degree on chance, and so it is beyond the capacity of a democracy to reward virtue regularly. Partial success comes within reach when political institutions and mores are well shaped; but without the support of a greater power, the 
goal will always remain elusive. But insofar as men can act confidently in the hope that their virtue will be rewarded - accomplishing much along the way - they will, in effect, have returned to a kind of religious faith from which politics may benefit. A democratic electorate can do God's work by seeing to it, as much as it can, that the virtuous are elected. Here is religion in the public square, as conservatives want, but not to promote religion, as liberals fear. 